\title{
Vocabulary Knowledge Students of Indonesian Language Text Books
}

\author{
Atikah Solihah, Applied Linguistics of Graduate Program, Universitas Negeri Jakarta (UNJ), \\ atikahsolihah_7317167488@mhs.unj.ac.id \\ Yumna Rasyid, Applied Linguistics of Graduate Program, Universitas Negeri Jakarta, \\ yumna.rasyid@unj.ac.id \\ Siti Gommo Attas, Applied Linguistics of Graduate Program, Universitas Negeri Jakarta, \\ sitigomoattas@unj.ac.id \\ Winci Firdaus, Badan Pengembangan dan Pembinaan Bahasa,Wincifirdaus1@gmail.com
}

\begin{abstract}
Understanding the vocabulary contained in a book is the door to a complete understanding of the book. The percentage of vocabulary that is understood will be a marker of whether the material in the book is understood by students or not. With this background, research on students' vocabulary understanding of Indonesian textbooks is important. This research is the first step in the research on vocabulary enrichment book development. The approach taken is quantitative with descriptive methods. The data collection technique used a survey with an instrument in the form of a questionnaire. Respondents in this study were $7^{\text {th }}$ grade, $8^{\text {th }}$ grade, and $9^{\text {th }}$ grade students in the junior high school. The results of the study were in the form of a vocabulary profile and students' vocabulary understanding. Seventh grade textbooks have a vocabulary type of 6,220 with a token of 50,051, eighth grade textbooks have a vocabulary type of 6,301 with a token of 46,904 and ninth grade textbooks have a type of vocabulary of 5,018 with a token of 33,926 . In $7^{\text {th }}$ grade there are 2,746 or $44 \%$ of the vocabulary with the frequency of using it only once written. Meanwhile, in $8^{\text {th }}$ grade there are 2,901 or a total of $46 \%$ vocabulary and in $9^{\text {th }}$ grade there are 2,897 or $58 \%$ vocabulary with a frequency of written usage only once. From the research results it was also known that a number of $88 \%$ percent of students had experienced difficulty understanding vocabulary. In addition, from 200 randomly selected vocabularies, it is known that the percentage of vocabulary commonly used by students is only $28 \%$ in $7^{\text {th }}$ grade, $31 \%$ in $8^{\text {th }}$ grade, and $39 \%$ in $9^{\text {th }}$ grade. These results indicate that further research is needed on the development of enrichment books that can improve students' understanding of vocabulary.
\end{abstract}

Keywords: knowledge, vocabulary, textbooks

Received: 05.11.2020

Accepted: 07.12.2020

Published: 05.01.2021

\section{INTRODUCTION}

The main teaching material for teachers is textbooks because these books are teaching materials that interact directly and intensively with students and teachers. In addition, there are enrichment books that can enhance knowledge for students. In Indonesian lessons, students' understanding of the vocabulary of textbooks is a door in understanding the subject matter. Therefore, research on understanding the vocabulary of students' of Indonesian textbooks is important.

Cruse states that the vocabulary is a whole collection of words that are randomly scattered in the mental area which have been partially arranged in various levels (Cruse, 2000: 179). Cain and Oakhill (2006) stated that generally low language skills also indicate limited vocabulary mastery. In this context, vocabulary becomes very important in language learning which includes four language skills.

Pikulski and Templeton (2004) stated that the vocabulary used by a person in spoken and written language is different. In line with this, Notion (2001) stated that the vocabulary used in communication must be around 2,000. Pikulski divides the vocabulary into four levels. Level I is the vocabulary used in communicating every day. Level II refers to the vocabulary used in reading or understanding instructions. Level III refers to vocabulary used in studying and undergoing certain professions. Level IV refers to specific vocabulary that is not used generally in education and is not associated with a particular profession.

Research on textbooks has been carried out by several people. Asri analyzes textbooks based on four components, namely the components of content, presentation, language, and graphics (Asri, 2017). The linguistic component mentions weaknesses in the linguistic material side. Román et al. (2016) 
reported that the linguistic cohesion used in texts in secondary schools includes four things, namely contrastive, elaborative, inferential, and temporal links.

\section{METODOLOGY}

The approach of this research is a combination of qualitative and qualitative. The quantitative approach is carried out with a descriptive method. The data collection technique was carried out by conducted a survey on junior high school students $\left(7^{\text {th }}\right.$ grade, $8^{\text {th }}$ grade and $9^{\text {th }}$ grade). Research sites is in Jakarta, Depok, Bekasi and Tangerang. The instrument given to the respondents is an online questionnaire. The data obtained were analyzed descriptively. A qualitative approach is carried out with content analysis techniques. The corpus used is Indonesian language textbooks for $7^{\text {th }}$ grade, $8^{\text {th }}$ grade and $9^{\text {th }}$ grade .

\section{RESULT}

The needs analysis carried out in this development research resulted in a description of the vocabulary profile in Indonesian language textbooks and the students' needs for understanding the vocabulary contained in Indonesian language textbooks.

Indonesian language textbooks whose vocabulary profiles were analyzed were Indonesian text books for $7^{\text {th }}$ grade, $8^{\text {th }}$ grade and $9^{\text {th }}$ grade. The Indonesian textbook for $7^{\text {th }}$ grade has a vocabulary type of 6,220 with a token of 50,051. The Indonesian textbook for $8^{\text {th }}$ grade has a type of vocabulary of 6,301 with tokens of 46,904 . The Indonesian textbook for $9^{\text {th }}$ grade has a vocabulary type of 5,018 with a token of 33,926 . The vocabulary profile can be seen in the following table.

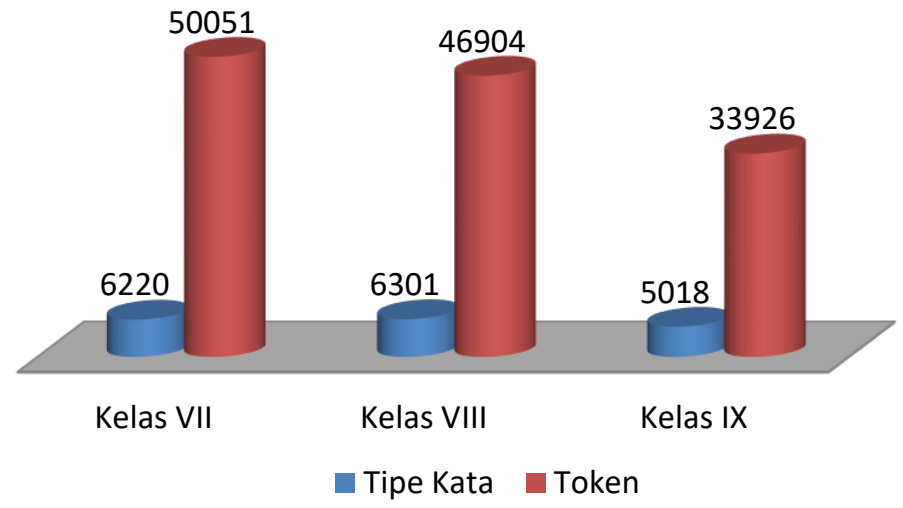

Figure 1. Types of Words and Tokens

In terms of students' needs for vocabulary understanding, the results showed that $6 \%$ of students never had difficulty of understanding the vocabulary contained in textbooks. A number of $88 \%$ of students have experienced difficulties of understanding vocabulary in textbooks. Meanwhile, some $6 \%$ also often experience difficulties. Thus, it can be seen that when reading Indonesian textbooks, it is known that quite a lot of students have experienced difficulty of understanding vocabulary. The survey results are summarized in the following figure.

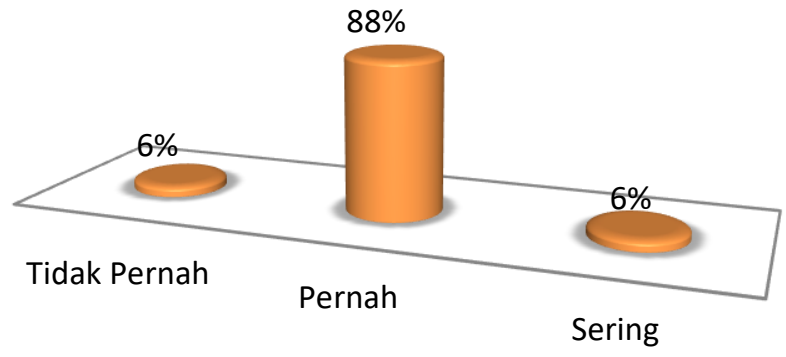

$\square$ Persentasi Peserta Didik

Figure 2. Difficulty in Understanding Vocabulary 
From the results of the study it is shown that 200 words with low frequency contained in Indonesian textbooks have an average of $16 \%$ of the vocabulary that is unknown to $7^{\text {th }}$ grade students. Meanwhile, the average vocabulary that is only known or known is $28 \%$, the average vocabulary that is known but rarely used is 28 , and the average commonly used vocabulary is $28 \%$. This can be illustrated in the following picture.

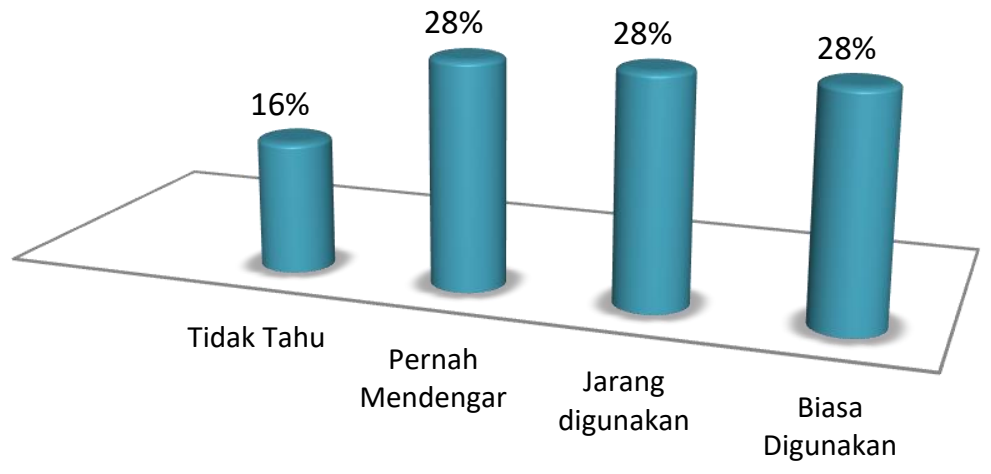

Figure 3. Percentage of 200 Word Understanding

Regarding the number of vocabulary, we can relate it to Notion's statement that the vocabulary used in communication must be around 2,000. These words often appear in communication so that they can be used as a basis for explaining the new vocabulary that is learned (Notion, 2001). Thus, if linked to textbooks, at least each textbook in it must contain 2,000 words that are known and used by students.

The $7^{\text {th }}$ grade Indonesian textbook has a vocabulary type of 6,220 with a token of 50,051. These types of words include various types of words, namely nouns, pronouns, verbs, adjectives, adverbs, numeralia, conjunctions, prepositions, and particles. Of the total word types, there are 20 types of words that have the highest frequency of usage. The vocabulary is the word which is, and, with, in, the text, on, language, word, for, not, in, from, Indonesian, story, letter, this, or, sentence, part, and you.

The $8^{\text {th }}$ grade Indonesian textbook has a vocabulary type of 6,301 with a token of 46,904 . These types of words include various types of words, namely nouns, pronouns, verbs, adjectives, adverbs, numeralia, conjunctions, prepositions, and particles. Of the total word types, there are 20 types of words that have the highest frequency of usage. The vocabulary is the word which is, and, with, that, in, the text, in, the word, you, for, from, that, on, not, or, this, Indonesia, advertisement, language and books.

The $9^{\text {th }}$ grade Indonesian textbooks have a type of vocabulary of 5,018 with a token of 33,926. These types of words include various types of words, namely nouns, pronouns, verbs, adjectives, adverbs, numeralia, conjunctions, prepositions, and particles. Of the total word types, there are 20 types of words that have the highest frequency of usage. The vocabulary is the word which is, and, in, with, not, in, that, for, or, from, person, language, text, word, I, this, Indonesia, book, exists, and will.

The new vocabulary to be introduced does not exceed the number of known vocabularies. In this connection, words that are newly introduced and which are rarely used are not the words that dominate the textbooks. Thus, vocabulary that is often used has more role in providing context and explaining words that are considered difficult and words that are rarely used (Santrock, 2008). Therefore, in this section it is necessary to know vocabulary with high frequency and vocabulary with low frequency.

The types of words with the highest number were in books of $8^{\text {th }}$ grade, which were 6,301, while the low number of types of words were in books of $9^{\text {th }}$ grade, namely 5,018. Meanwhile, the highest number of tokens was found in $7^{\text {th }}$ grade books, namely 50,051. Even though $8^{\text {th }}$ grade books have the highest number of word types, the tokens in the books are lower than in $7^{\text {th }}$ grade textbooks. The following is a comparison of the number of word types and tokens in Indonesian textbooks between $7^{\text {th }}$ grade, $8^{\text {th }}$ grade and $9^{\text {th }}$ grade.

High word frequency can be described by looking at the number of words contained in the seventh grade textbook. A word type that appears with a frequency of use of 1,555 times. Word types and occurs with a frequency of 1,368 times.

The use of writing with the largest number is found in words with the frequency of usage reaching 1,555 times. This amount is $3.079 \%$ of all word usage contained in the seventh grade textbook. The other four vocabularies with the largest usage were words and with a usage frequency of $2.709 \%$, 
words with a usage frequency of $1.606 \%$, words with a usage frequency of $1.242 \%$, and text with a usage frequency of $1.012 \%$. The percentage of vocabulary usage can be seen in the following figure.

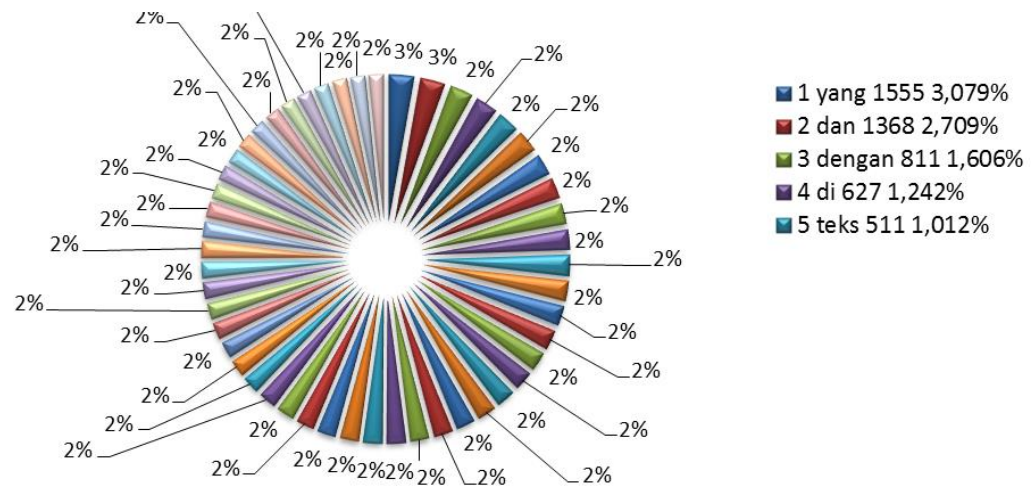

Figure 4. Frequency of Seventh Grade Textbook Word Types

The frequency of using the type of vocabulary in $7^{\text {th }}$ grade textbooks can be described by looking at the number that appears in the $8^{\text {th }}$ grade Kurtilas book. The use of writing with the largest number is found in words with the frequency of usage reaching 1,555 times. This amount is $3.079 \%$ of all word usage contained in the $8^{\text {th }}$ grade Kurtilas book. The other four vocabularies with the largest usage were words and with a usage frequency of $2.709 \%$, words with a usage frequency of $1.606 \%$, di words with a usage frequency of $1.242 \%$, and text with a usage frequency of $1.012 \%$. The percentage of vocabulary usage can be seen in the following figure.

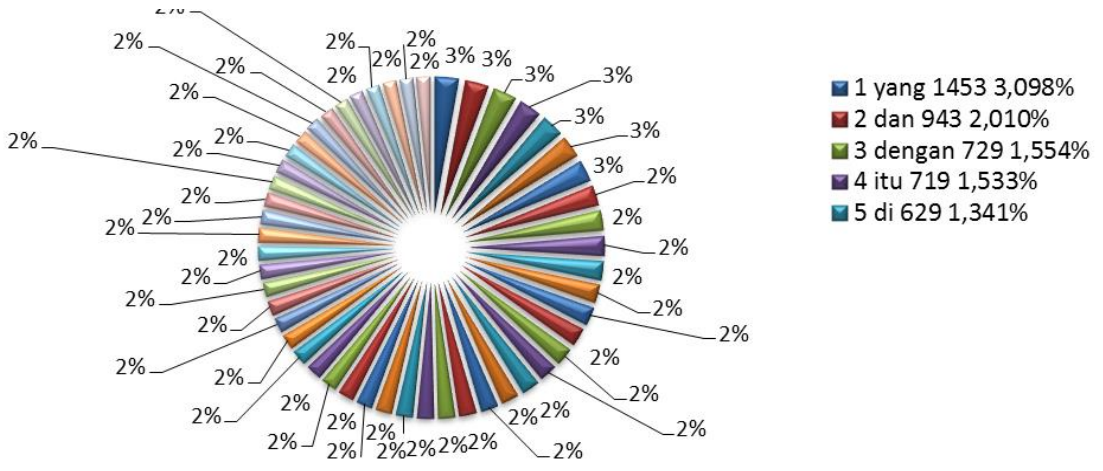

Figure 5. Frequency of Eighth Grade Textbook Word Types

The frequency of use of this type of vocabulary can be described by looking at the number that appears in the $9^{\text {th }}$ grade Kurtilas book. The use of writing with the largest number is found in words with the number of frequency usage reaching 1,074 times. This amount is $3.2 \%$ of all word usage contained in the $9^{\text {th }}$ grade Kurtilas book. The other four vocabularies with the other highest usage are words and with a usage frequency of $2.5 \%$, words with a usage frequency of $1.2 \%$, words with a usage frequency of $1.1 \%$, and not with a usage frequency of $1.1 \%$. $0.9 \%$. The percentage of vocabulary usage can be seen in the following figure.

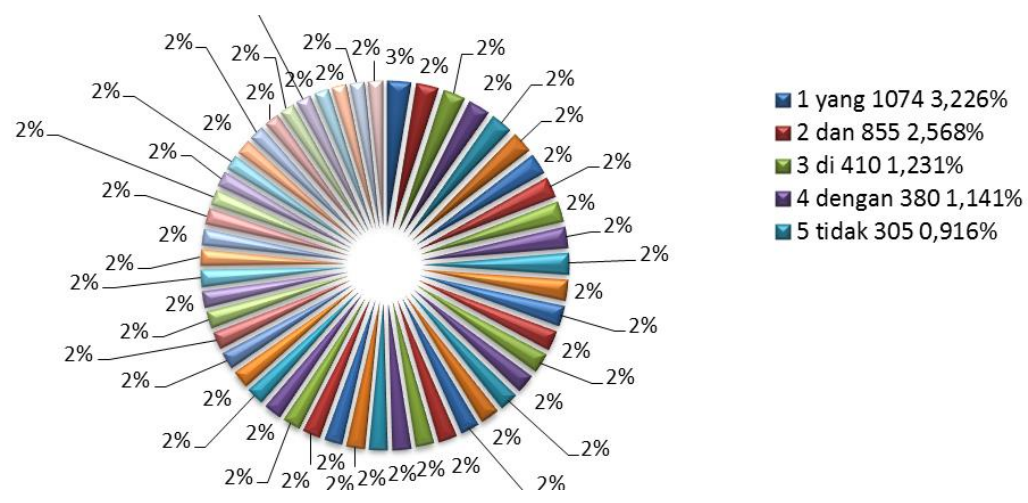

Figure 6. Frequency of Ninth Grade Textbook Word Types 
In addition to the vocabulary with the highest written usage, there are also the types with the lowest usage. In the seventh grade textbook, 2,746 vocabularies have been identified with only one written usage. If it is known that the number of word types in the $7^{\text {th }}$ grade Kurtilas book is 6,220, the type of vocabulary which occurs only once is $44 \%$ of the existing word types. These conditions can be described as follows.

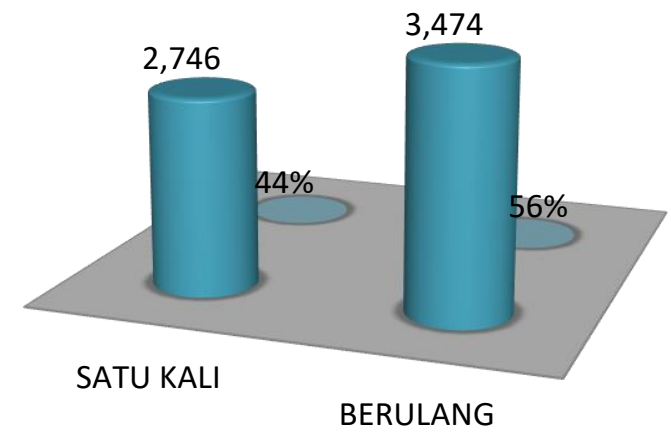

Figure 7. Frequency Level of Type of Words for Seventh Grade Books

In the eighth grade textbook, 2,901 vocabularies have been identified with only one written usage, in other words a low frequency. If it is known that the number of word types in $8^{\text {th }}$ grade textbooks is 6,301, the type of vocabulary which occurs only once reaches $46 \%$ of the existing word types. These conditions can be described as follows.

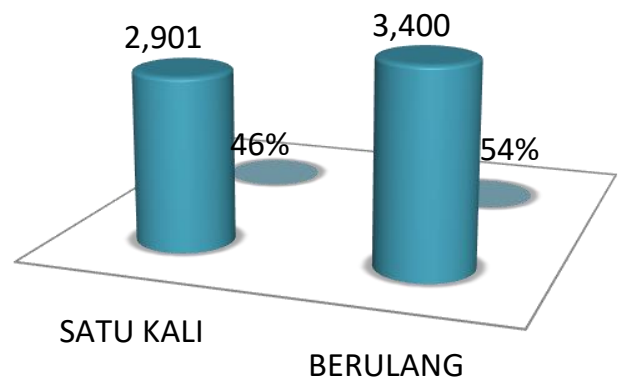

Figure 8. Frequency Level of Type of Words for Eighth Grade Books

In the $9^{\text {th }}$ Grade textbook, 2,897 vocabularies have been identified with only one written usage. If it is known that the number of word types in $9^{\text {th }}$ grade is 5,108 , the type of vocabulary which occurs only once reaches $58 \%$ of the existing word types. These conditions can be described as follows.

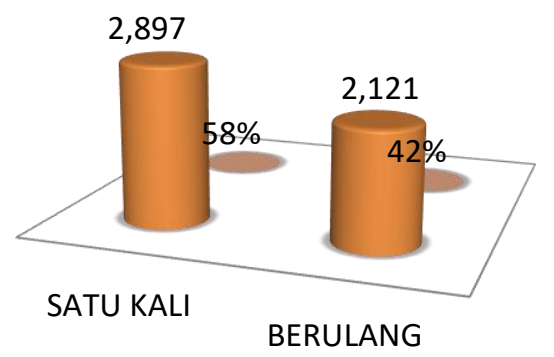

Figure 9. Frequency Level of Type of Words for Eighth Grade Books 


\section{Descriptions of Students' Needs for Vocabulary Understanding}

To find out the students' needs for understanding vocabulary, specifically those contained in Indonesian language textbooks, a needs analysis survey was conducted. The survey was attended by 177 junior high school students, equivalent from Jakarta, Depok, Bekasi, Bogor and Tangerang. The following is the profile of the surveyed students.

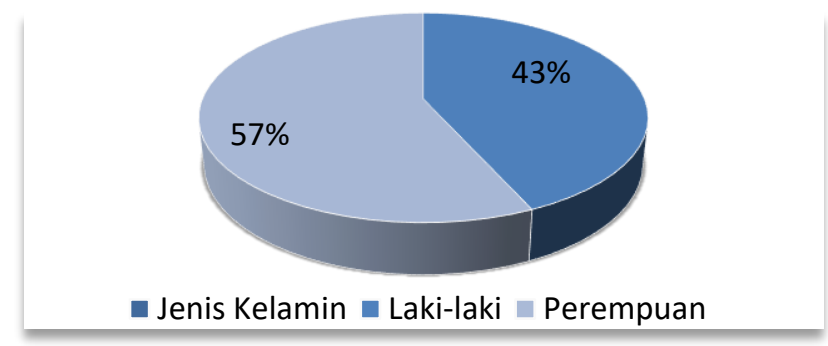

Figure 10. Proportion of Learners

From the survey results it is known that a number of $6 \%$ of students have never had difficulty understanding the vocabulary contained in textbooks. A number of $88 \%$ of students have experienced difficulties understanding vocabulary in textbooks. Meanwhile, some $6 \%$ also often experience difficulties. Thus, it can be seen that when reading Indonesian textbooks, it is known that quite a lot of students have experienced difficulty understanding vocabulary. The survey results are summarized in the following figure.

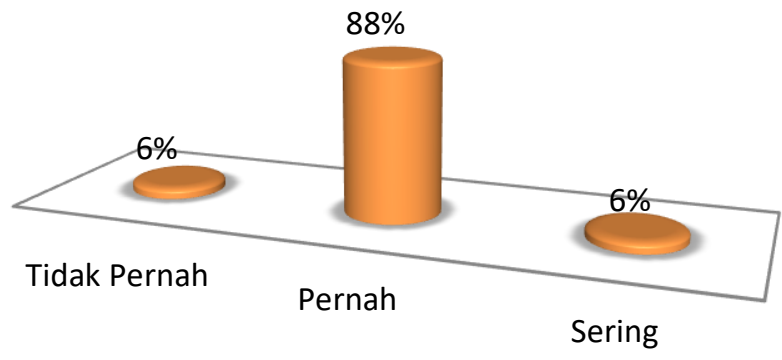

$\square$ Persentasi Peserta Didik

\section{Figure 11. Word Understanding Difficulties}

From the survey results it was also known that most students would ask the teacher or parent when they did not understand the vocabulary in question. However, we know that this process has limitations, both at the meeting time and the ability of parents and teachers to answer students' questions. The number of participants who chose to ask questions of parents and teachers was $77 \%$. The number of people who look at the dictionary to find out the meaning of a word is $18 \%$. Meanwhile, there were $5 \%$ who ignored it or did nothing.

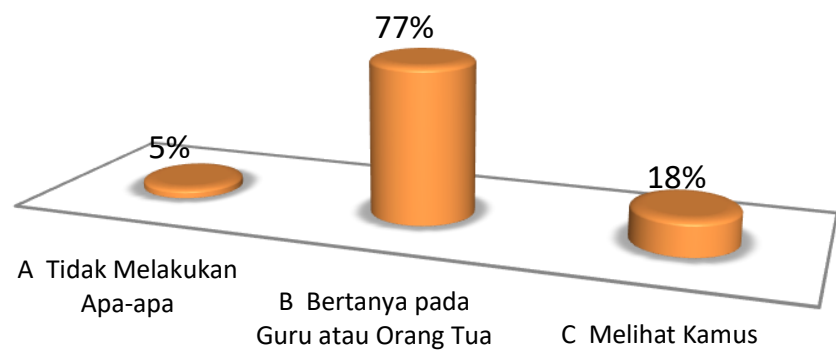

$\square$ Persentase Peserta Didik

Figure12. Student Behavior 
In relation to the needs of junior high school students for understanding vocabulary, it can be juxtaposed with what Cruse said, which states that vocabulary is a whole collection of words that are randomly scattered in a mental area, some of which have been arranged in various levels (Cruse, 2000: 179). So, the study of vocabulary does not only refer to the number of words contained in a language, but includes the arrangement of the vocabulary at various levels. The levels referred to are related to their form, spoken media, speakers, social class, age, situation, and so on. Language speakers randomly load the various levels of the vocabulary in their mental area to be used according to their communication needs. The composition of the vocabulary can be seen in terms of morphology, semantics, or pragmatics. Junior high school level students in Indonesia are in the age range 11--15 years. As stated by Santrock, at that age students have the possibility to understand vocabulary in abstract form or with connotative meanings which are still limited to information relating to their life and their needs in communicating.

\section{Vocabulary Usage Conditions}

The use of vocabulary contained in Indonesian language textbooks was examined through survey results. From the results of the survey, it was found that students' understanding of vocabulary at a very low level of frequency, namely one appearance in Indonesian lessons. The following is the vocabulary.

From the results of the study it is known that 200 words with low frequency contained in Indonesian textbooks have an average of $16 \%$ of the vocabulary that is unknown or unknown to $7^{\text {th }}$ grade students. Meanwhile, the average vocabulary that is only known or known is $28 \%$, the average vocabulary that is known but rarely used is 28 , and the average commonly used vocabulary is $28 \%$. This can be illustrated in the following picture.

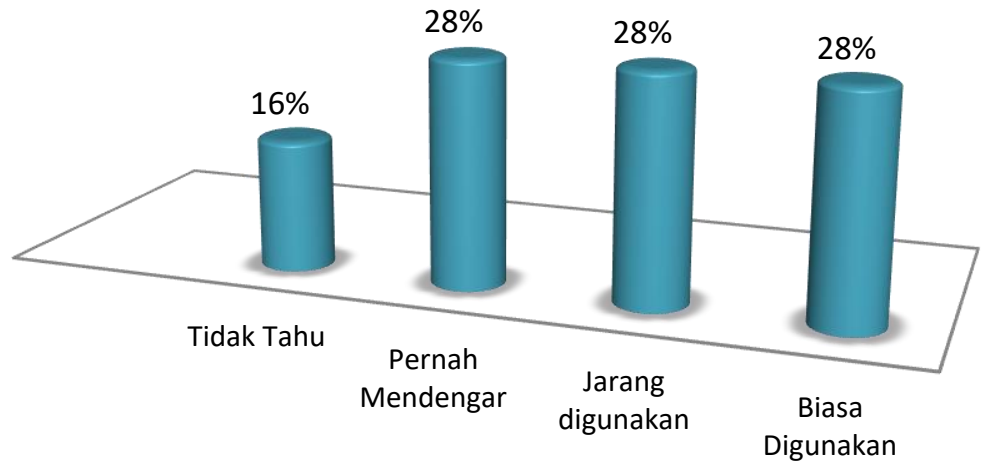

Figure 13. Percentage of 200 Word Understanding by Seventh Grade Students

Of the 200 vocabularies, it can be specifically examined the understanding of vocabulary that has undergone word formation. The following are the results of the test for students' understanding of vocabulary with affixes or those that have experienced affixes.

Table 1. Seventh Grade Affixed Vocabulary Comprehension

\begin{tabular}{|l|l|l|l|l|l|l|}
\hline No. & Vocabulary & \multicolumn{2}{|l|}{$\begin{array}{l}\text { Unkow } \\
\text { n }\end{array}$} & \multicolumn{2}{l}{$\begin{array}{l}\text { Has been } \\
\text { heard }\end{array}$} & \multicolumn{2}{l}{$\begin{array}{l}\text { Known, but } \\
\text { seldom used }\end{array}$} & Often used \\
\hline 1 & berarsitektur & $25 \%$ & $34 \%$ & $25 \%$ & $16 \%$ \\
\hline 2 & berfantasilah & $16 \%$ & $29 \%$ & $28 \%$ & $28 \%$ \\
\hline 3 & berkesinambungan & $24 \%$ & $36 \%$ & $23 \%$ & $18 \%$ \\
\hline 4 & berperspektif & $24 \%$ & $41 \%$ & $26 \%$ & $9 \%$ \\
\hline 5 & dehumanisasi & $68 \%$ & $19 \%$ & $10 \%$ & $3 \%$ \\
\hline 6 & dianalisis & $13 \%$ & $23 \%$ & $36 \%$ & $28 \%$ \\
\hline 7 & dieksplisitkan & $59 \%$ & $20 \%$ & $14 \%$ & $6 \%$ \\
\hline 8 & inkonvensional & $53 \%$ & $30 \%$ & $13 \%$ & $5 \%$ \\
\hline 9 & memfantasikan & $10 \%$ & $34 \%$ & $31 \%$ & $24 \%$ \\
\hline 10 & memfasilitasi & $10 \%$ & $19 \%$ & $30 \%$ & $41 \%$ \\
\hline
\end{tabular}




\begin{tabular}{|l|l|l|l|l|l|}
\hline 11 & mengarantina & $26 \%$ & $35 \%$ & $24 \%$ & $14 \%$ \\
\hline 12 & mengkonkretkan & $34 \%$ & $30 \%$ & $23 \%$ & $11 \%$ \\
\hline 13 & pendokumentasian & $11 \%$ & $28 \%$ & $36 \%$ & $25 \%$ \\
\hline 14 & penelaahan & $11 \%$ & $20 \%$ & $31 \%$ & $36 \%$ \\
\hline 15 & penyelia & $58 \%$ & $24 \%$ & $15 \%$ & $4 \%$ \\
\hline 16 & peradangan & $8 \%$ & $24 \%$ & $35 \%$ & $34 \%$ \\
\hline 17 & prakarsai & $31 \%$ & $30 \%$ & $20 \%$ & $18 \%$ \\
\hline 18 & superordinat & $64 \%$ & $26 \%$ & $8 \%$ & $3 \%$ \\
\hline 19 & terintegrasi & $20 \%$ & $38 \%$ & $20 \%$ & $21 \%$ \\
\hline 20 & tersengal & $29 \%$ & $33 \%$ & $23 \%$ & $15 \%$ \\
\hline
\end{tabular}

Affixed words, such as explicit, dehumanized, superordinate, unconventional, and supervisor have a very high percentage of students' ignorance of more than 50\%. Other words that have been affixed such as quarantine and continuous also have a fairly large percentage of ignorance or on the other hand have a very low percentage of usage.

Preliminary research conducted on the $8^{\text {th }}$ Grade Indonesian Language Kurtilas book revealed that of the 200 vocabulary words with very low frequency contained in the $8^{\text {th }}$ Grade VIII Indonesian Language Kurtilas book, it was known that an average of $18 \%$ were unknown or unknown to the $8^{\text {th }}$ graders. Meanwhile, the average vocabulary that is only known or known is $19 \%$, the average vocabulary that is known but rarely used is $32 \%$, and the average vocabulary that is commonly used is $31 \%$.

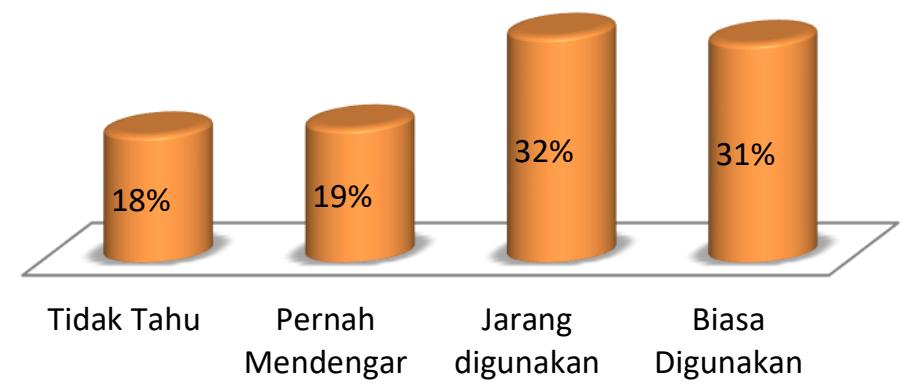

Figure 14. Percentage of 200 Word Understanding by Eighth Grade Students

Of the 200 vocabularies, it can be specifically examined the understanding of vocabulary that has undergone word formation. The following are the results of the test for students' understanding of vocabulary with affixes or those that have experienced affixes.

Table 2. Eighth Grade Affixed Vocabulary Comprehension

\begin{tabular}{|l|l|l|l|l|l|}
\hline No. & Vocabulary & Unknown & $\begin{array}{l}\text { Has been } \\
\text { heard }\end{array}$ & $\begin{array}{l}\text { Known but } \\
\text { seldom used }\end{array}$ & Often used \\
\hline 1 & penyelia & $77 \%$ & $14 \%$ & $5 \%$ & $5 \%$ \\
\hline 2 & digubah & $55 \%$ & $45 \%$ & $0 \%$ & $0 \%$ \\
\hline 3 & berdalih & $50 \%$ & $23 \%$ & $23 \%$ & $5 \%$ \\
\hline 4 & memparafrasakannya & $50 \%$ & $18 \%$ & $18 \%$ & $14 \%$ \\
\hline 5 & cerpenis & $45 \%$ & $36 \%$ & $14 \%$ & $5 \%$ \\
\hline 6 & membumbung & $45 \%$ & $23 \%$ & $18 \%$ & $9 \%$ \\
\hline 7 & bertajuk & $41 \%$ & $14 \%$ & $32 \%$ & $14 \%$ \\
\hline 8 & gencatan & $41 \%$ & $36 \%$ & $18 \%$ & $5 \%$ \\
\hline 9 & kecaman & $41 \%$ & $14 \%$ & $32 \%$ & $14 \%$ \\
\hline 10 & penutur & $41 \%$ & $23 \%$ & $23 \%$ & $9 \%$ \\
\hline 11 & dentingan & $36 \%$ & $14 \%$ & $36 \%$ & $14 \%$ \\
\hline 12 & dimutakhirkan & $36 \%$ & $36 \%$ & $14 \%$ & $14 \%$ \\
\hline
\end{tabular}




\begin{tabular}{|l|l|l|l|l|l|}
\hline 13 & diusung & $36 \%$ & $36 \%$ & $18 \%$ & $9 \%$ \\
\hline 14 & kesinambungan & $36 \%$ & $27 \%$ & $32 \%$ & $5 \%$ \\
\hline 15 & lonjakan & $36 \%$ & $27 \%$ & $27 \%$ & $9 \%$ \\
\hline 16 & tertegun & $36 \%$ & $14 \%$ & $41 \%$ & $9 \%$ \\
\hline 17 & multitafsir & $32 \%$ & $55 \%$ & $9 \%$ & $5 \%$ \\
\hline 18 & digarap & $27 \%$ & $32 \%$ & $36 \%$ & $5 \%$ \\
\hline 19 & berdebur & $23 \%$ & $27 \%$ & $41 \%$ & $9 \%$ \\
\hline 20 & menghela & $14 \%$ & $14 \%$ & $27 \%$ & $45 \%$ \\
\hline
\end{tabular}

Affixed words, such as supervisor, composed, quibble, and paraphrase them have a very high percentage of students' ignorance of more than $50 \%$. Other vocabularies that have been affixed such as short stories and cessation also have a sizable percentage of ignorance or on the other hand have a very low percentage of usage.

Preliminary research was also carried out in $9^{\text {th }}$ grade Indonesian language textbooks. The preliminary research revealed that of the 200 vocabulary words with very low frequency contained in the $9^{\text {th }}$ grade Kurtilas book, it was known that an average of $12 \%$ were unknown or unknown to $9^{\text {th }}$ grade students. Meanwhile, the average vocabulary that is only known or known is $18 \%$, the average vocabulary that is known but rarely used is $31 \%$, and the average vocabulary that is commonly used is $39 \%$.

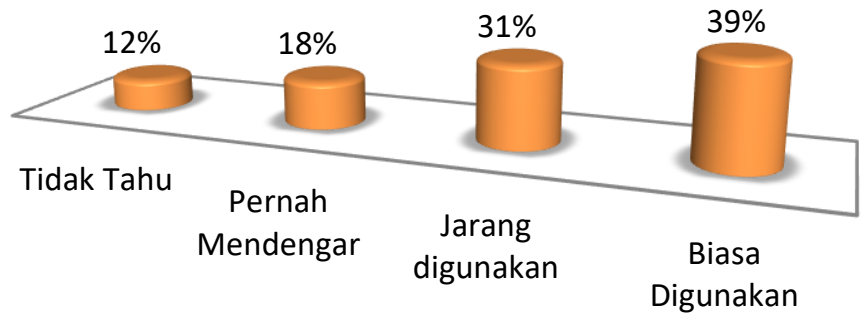

Figure 15. Percentage of 200 Word Understanding by Ninth Grade Students

Of the 200 vocabularies, it can be specifically examined the understanding of vocabulary that has undergone word formation. The following are the results of the test for students' understanding of vocabulary with affixes or those that have experienced affixes.

Table 3. Ninth Grade Affixed Vocabulary Comprehension

\begin{tabular}{|l|l|l|l|l|l|}
\hline No. & Vocabulary & Unknown & $\begin{array}{l}\text { Has been } \\
\text { heard }\end{array}$ & $\begin{array}{l}\text { Known but } \\
\text { seldom used }\end{array}$ & Often used \\
\hline 1 & berkelindan & $73 \%$ & $13 \%$ & $7 \%$ & $4 \%$ \\
\hline 2 & jambangan & $53 \%$ & $29 \%$ & $13 \%$ & $4 \%$ \\
\hline 3 & penyelia & $53 \%$ & $29 \%$ & $13 \%$ & $4 \%$ \\
\hline 4 & berseloroh & $51 \%$ & $24 \%$ & $18 \%$ & $4 \%$ \\
\hline 5 & bertandang & $42 \%$ & $24 \%$ & $22 \%$ & $7 \%$ \\
\hline 6 & menstimulus & $31 \%$ & $42 \%$ & $18 \%$ & $9 \%$ \\
\hline 7 & berkutat & $27 \%$ & $24 \%$ & $38 \%$ & $9 \%$ \\
\hline 8 & mencicit & $24 \%$ & $20 \%$ & $40 \%$ & $16 \%$ \\
\hline 9 & menyunggingkan & $22 \%$ & $27 \%$ & $38 \%$ & $13 \%$ \\
\hline 10 & membesut & $20 \%$ & $36 \%$ & $38 \%$ & $7 \%$ \\
\hline 11 & melumat & $18 \%$ & $36 \%$ & $33 \%$ & $11 \%$ \\
\hline 12 & terealisasi & $16 \%$ & $22 \%$ & $38 \%$ & $24 \%$ \\
\hline 13 & menarasikan & $13 \%$ & $16 \%$ & $42 \%$ & $29 \%$ \\
\hline 14 & tertatih & $9 \%$ & $20 \%$ & $38 \%$ & $33 \%$ \\
\hline 15 & kelayakan & $9 \%$ & $11 \%$ & $36 \%$ & $44 \%$ \\
\hline 16 & kepekatan & $9 \%$ & $20 \%$ & $29 \%$ & $42 \%$ \\
\hline 17 & berperspektif & $7 \%$ & $24 \%$ & $38 \%$ & $29 \%$ \\
\hline
\end{tabular}




\begin{tabular}{|l|l|l|l|l|l|}
\hline 18 & keterbacaan & $7 \%$ & $16 \%$ & $33 \%$ & $44 \%$ \\
\hline 19 & mendongkrak & $7 \%$ & $18 \%$ & $44 \%$ & $29 \%$ \\
\hline 20 & berorientasi & $4 \%$ & $20 \%$ & $31 \%$ & $44 \%$ \\
\hline
\end{tabular}

From the three books, it can be seen that the percentage of vocabulary that is unknown and only ever heard by students without being used is still quite large, $16 \%$ and $28 \%$ in $7^{\text {th }}$ grade, $18 \%$ and $19 \%$ in $8^{\text {th }}$ grade, and $12 \%$ and $18 \%$ in $9^{\text {th }}$ grade. Meanwhile, the vocabulary used by students did not reach $50 \%$, both in $7^{\text {th }}$ grade, $8^{\text {th }}$ grade and $9^{\text {th }}$ grade. Thus, the potential for improving students' understanding of Indonesian language lessons through enrichment of vocabulary aspects is still quite large.

These results are actually consistent with what was conveyed by Garcia, who stated that teachers or in this case interested parties in learning can encourage learners' vocabulary mastery in other ways. Textbooks contain vocabulary that students may not fully understand. For some students, dealing with textbooks may be very difficult. As a result, a teacher can add to the textbook something that is missing from it: for example, clarifying orally the purpose of a reading, helping students relate what they will read with the knowledge they already have, or monitoring their understanding and learning processes (García, 2018: 16- -26).

The use of varied vocabulary in textbooks can help students if they are introduced in a guided manner in the learning process. However, it is less meaningful if vocabulary variations are not given special treatment in learning. (Ma, 2013: 237--246). This research strengthens Sunderland's research on the role of teachers in word choice in gender-biased textbooks (Sunderland, 2001: 251--286).

Thus, it can be concluded that the results of the conditions for using the vocabulary ensure the students' needs for vocabulary enrichment books related to vocabulary.

\section{CONCLUSION}

The $7^{\text {th }}$ grade Indonesian textbook has a vocabulary type of 6,220 with a token of 50,051 . The $8^{\text {th }}$ grade Indonesian textbook has a vocabulary type of 6,301 with a token of 46,904 . The $9^{\text {th }}$ grade Indonesian textbooks have a type of vocabulary of 5,018 with a token of 33,926.

The types of words with the highest number were in books of $8^{\text {th }}$ grade, which were 6,301, while the low number of types of words were in books of $9^{\text {th }}$ grade, namely 5.018. Meanwhile, the highest number of tokens was found in book 7 th grade books, namely 50,051.

In addition to the vocabulary with the highest written usage, there are also the types with the lowest usage. In the seventh grade textbook, 2,746 vocabularies have been identified with only one written usage. In the eighth grade textbook, 2,901 vocabularies have been identified with only one written usage, in other words a low frequency. In the $9^{\text {th }}$ grade textbook, 2,897 vocabularies have been identified with only one written usage.

From the survey results it is known that a number of $6 \%$ of students have never had difficulty understanding the vocabulary contained in textbooks. A number of $88 \%$ of students have experienced difficulties understanding vocabulary in textbooks. Meanwhile, some $6 \%$ often experience difficulties. Thus, it can be seen that when reading Indonesian textbooks, it is known that quite a lot of students have experienced difficulty understanding vocabulary.

From the results of the study of vocabulary use, it is known that 200 words with low frequency contained in Indonesian language textbooks on an average of $16 \%$ of the vocabulary are unknown or unknown to $7^{\text {th }}$ grade students. Meanwhile, the average vocabulary that is only known or known is $28 \%$, the average vocabulary that is known but rarely used is 28 , and the average vocabulary that is commonly used is $28 \%$.

Preliminary research conducted on the $8^{\text {th }}$ grade Indonesian Language Kurtilas book revealed that of the 200 vocabulary words with very low frequency contained in the $8^{\text {th }}$ grade Indonesian Language Kurtilas book, it is known that an average of $18 \%$ is unknown or unknown to the $8^{\text {th }}$ graders. Meanwhile, the average vocabulary that is only known or known is $19 \%$, the average vocabulary that is known but rarely used is $32 \%$, and the average vocabulary that is commonly used is $31 \%$.

Preliminary research was also carried out in $9^{\text {th }}$ grade Indonesian language textbooks. The preliminary research revealed that of the 200 vocabulary words with very low frequency contained in the $9^{\text {th }}$ grade Kurtilas books, it was known that an average of $12 \%$ were unknown or unknown to $9^{\text {th }}$ grade students. Meanwhile, the average vocabulary that is only known or known is $18 \%$, the average vocabulary that is known but rarely used is $31 \%$, and the average vocabulary that is commonly used is $39 \%$.

From the three books, it can be seen that the percentage of vocabulary that is unknown and only ever heard by students without being used is still quite large, $16 \%$ and $28 \%$ in $7^{\text {th }}$ grade, $18 \%$ and $19 \%$ in $8^{\text {th }}$ grade, and $12 \%$ and $18 \%$ in $9^{\text {th }}$ grade. Meanwhile, the vocabulary used by students did not reach $50 \%$, 
both in $7^{\text {th }}$ grade, $8^{\text {th }}$ grade and $9^{\text {th }}$ grade. Thus, the potential for improving students' understanding of Indonesian language lessons through enrichment of vocabulary aspects is still quite large.

\section{ACKNOWLEDGEMENTS}

The authors would like to thank the promoters and copromotor in this study, namely Yumna Rasyid and Siti Gommo. In addition, thanks are also conveyed to the Head of National Language Development and Cuktivation, E. Aminuddin Aziz who has provided general input regarding this research. Thank you also to Triwulandari and Hijril Ismail for being a discussion partner.

\section{REFERENCE}

Alqahtani, Mofareh , 2015. International Journal of Teaching and Education "The Importance of Vocabulary in Language Learning and How to be Taught" Vol. III, Nomor 3 Tahun 2015 DOI: 10.20472 /TE.2015.3.3.002

Alwi, Hasan, 1992. Modalitas dalam Bahasa Indonesia, Jakarta: Kanisius.

Arka, I Wayan, 2011, On modality and finiteness in Indonesian: complexities ofnya nominalisation', Workshop on TAM markers and evidentiality in Indonesian Languages, Tokyo University of Foreign Studies. http://lingdy.aacore.jp/en/ contact/index.html

Anderson, Stephen R., 2005. Aspects of the theory of clitics. Oxford: Oxford University Press.

Anderson, StephenR., 2008. English reduced auxiliaries really are simple clitics. Linguee Linguaggio.

Aronoff, Mark dan Kirsten Fudeman, 2011. What is Morphology? Wesr Sussex: Blackwell Publishing 2nd edition.

Asri, A. Sharul, 2017. Retorika "Telaah Buku Teks Pegangan Guru dan Siswa pada Mata Pelajaran Bahasa Indonesia Kelas VII Berbasis Kurikulum 2013" Vol. 3, No. 1 April 2017, h. 70-82.

Badan Pengembangan dan Pembinaan Bahasa, 2017. Tata Bahasa Baku Bahasa Indonesia. Jakarta: Kemendikbud.

Barcroft, Joe, 2016. Applied Linguistics. Oxford University Press, Advance Access published

Cunningsworth, Alan, 1995. Choosing Your Corsebook. Cambridge: McMillan Education.

Cain, Kate dan Jane Oakhill, 2006. British Journal of Educational Psychology "Profiles of Children with Specific Reading Comprehension Difficulties". The British Psychological Society. h. Vol. 76, No. 4, 12 683-696.DOI https://doi.org/10.1348/000709905X67610

Calandruccio, Lauren, a Lori J. Leibold,b and Emily Bussc, 2016. American Journal of Audiology, "Linguistic Masking Release in School-Age Children and Adults, American Speech-Language-Hearing Association, Maret 2016, Vol. 25 h. 34-40. doi: 10.1044/2015_AJA-15-0053

Gerald J. Miller dan Kaifeng Yang, 2008. Handbook of Research Methods in Public Adminsitration. New York: CRC Press.

Ggraé, Philippe, 2013. Aspect in Indonesian: free markers versus bound markers . NUSA 55 [Permanent URL: http://hdl.handle.net/ 10108/74326]

Greenberg, Joseph H., 1963. Universals of Language, "Some Universal of Grammar with Particular Reference to The Order of Meaningful Element". London: Stanford University, MIT Press.

Kridalaksana, Harimurti, 2001. Kamus Linguistik. Jakarta: Gramedia Pustaka Utama.

Lee, Jackie F.K. (2014). A hidden curriculum in Japanese EFL textbooks: Genderrepresentation. Linguistic and Education. Volume 27, 39-53 . Siencedirect.com. https://doi.org/10.1016/j.linged.2014.07.002.

Ma, Qing. 2013. Matching vocabulary learning process with learning outcome in L2academic writing: An exploratory case study. Linguistics and Education Volume 24. Siencedirect.com. DOI:10.1016/J.LINGED.2012.11.002

Richards, Kendall and Nick Pilcher, 2016. Dialogic Pedagogy: An International Online Journal | http://dpj.pitt.edu DOI: 10.5195/dpj.2016.163 | Vol. 4

Ulla, Mark B.. 2017. Linguistic Needs and Language Skills: Implications for Curriculum Development . Duangkamon Winitkun, Thai Learners: International Journal of Instruction October 2017 g Vol.10, No.4

Zwicky, Arnold M. and Geoffrey K. Pullum., 1983. Cliticization vs. inflection: English n't. 59. English: Language. 


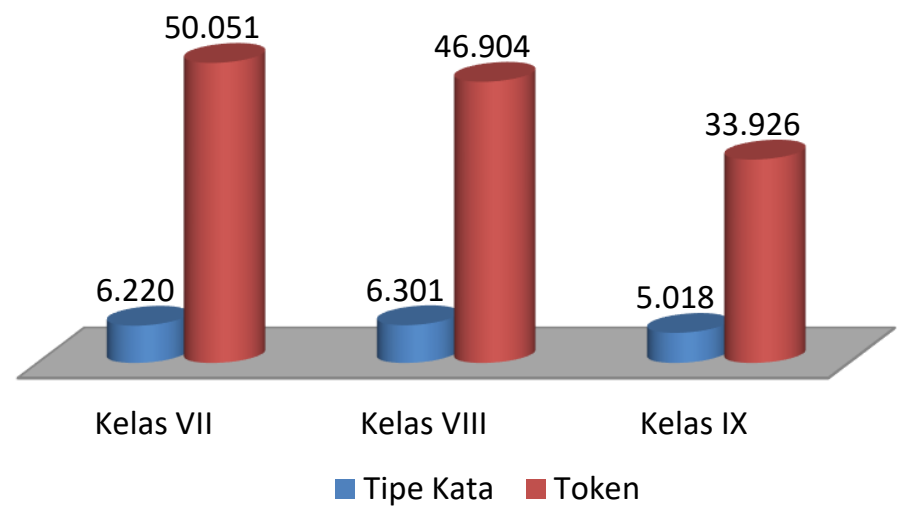

Figure 16. Types of Words and Tokens 